\title{
KARAKTERISTIK MIKROKAPSUL MINYAK EKSTRAK DARI KEPALA KAKAP MERAH PADA BEBERAPA RASIO BAHAN PENYALUT
}

\author{
Characteristics of Extract Oil Microcapsules from Red Snapper's Head \\ at Some Coating Material Ratio
}

\author{
Desiana Nuriza Putri*, Yessi Maulidhia Nugrahani Wibowo, Noor Harini \\ Program Studi Teknologi Pangan - Fakultas Pertanian Peternakan - Universitas Muhammadiyah Malang \\ Jl. Raya Tlogomas No. 246 - Malang 65144 \\ *Penulis Korespondensi, email: desiana@umm.ac.id
}

Disubmit : 22 Februari 2020 Direvisi : 30 April $2021 \quad$ Diterima : 26 Juli 2021

\begin{abstract}
ABSTRAK
Kepala ikan kakap merah merupakan limbah terbanyak yang dihasilkan dari industri fillet ikan kakap merah. Minyak ikan hasil ekstraksi dari limbah kepala ikan kakap merah mengandung asam lemak omega 3, omega 6 dan omega 9, namun bersifat kurang stabil dan mudah rusak akibat proses oksidasi. Stabilitas minyak ikan selama penyimpanan dapat ditingkatkan melalui proses mikroenkapsulasi dengan metode spray drying. Penelitian ini bertujuan untuk mengkaji pengaruh proporsi bahan penyalut yang berbeda terhadap karakteristik mikrokapsul minyak ikan yang dihasilkan. Penelitian menggunakan Rancangan Acak Kelompok dengan faktor perlakuan proporsi bahan penyalut yang terdiri dari 6 level. Analisis statistik pada data hasil penelitian dilakukan dengan menggunakan software SPSS 20 $(a=5 \%)$. Mikrokapsul dengan karakteristik terbaik dihasilkan dari perlakuan perbandingan antara bahan penyalut dekstrin dan gum arab 2:3, dengan rendemen $17,75 \%$, kadar air $11,32 \%$ (bb), kadar lemak 15,65\%, ukuran 1653,08 $\mu \mathrm{m}$ dan berwarna putih kekuningan. Selain itu, proses mikroenkapsulasi dengan bahan penyalut dekstrin dan gum arab (2:3) juga menunjukkan bahwa dapat mempertahankan kandungan asam lemak dengan jumlah omega 3 sebesar 14,17\%, omega 6 sebesar $4,35 \%$ dan omega 9 sebesar $12,53 \%$
\end{abstract}

Kata kunci: Dekstrin; Gum arab; Ikan Kakap Merah; Limbah; Mikroenkapsulasi

\begin{abstract}
Red snapper head is the most waste generated from the red snapper fillet industry. Fish oil extracted from red snapper head waste contains omega-3, omega-6, and omega-9 fatty acids but is less stable and easily damaged due to the oxidation process. The stability of fish oil during storage can be increased through the spray drying method's microencapsulation process. This study aims to examine the effect of different proportions of coating materials on the characteristics of the fish oil microcapsules produced. The study used a randomized block design with a treatment factor of the ratio of coating material consisting of 6 levels. Statistical analysis of research data was carried out using SPSS 20 software ( $a=5 \%)$. Microcapsules with the best characteristics were produced from the comparison treatment between dextrin and gum arabic coating materials $2: 3$, with a yield of $17.75 \%$, water content $11.32 \%$ (bb), fat content $15.65 \%$, size 1653.08 $m$, and colored yellowish white. In addition, the microencapsulation process with dextrin and gum arabic coating materials (2:3) also showed that it could maintain the fatty acid content with the amount of omega3 by $14.17 \%$, omega- 6 by $4.35 \%$, and omega- 9 by $12.53 \%$
\end{abstract}

Keywords: Dextrin; Gum arabic Microencapsulation; Red Snapper; Waste 


\section{PENDAHULUAN}

Industri pengolahan fillet ikan kakap merah hanya memanfaatkan bagian daging ikan yang berkisar antara $40-50 \%$, selebihnya menjadi limbah dan belum termanfaatkan secara optimal. Kepala ikan kakap merah merupakan salah satu limbah yang dihasilkan dengan jumlah terbanyak, yakni mencapai 30\% dari total bagian ikan (La Ifa et al., 2018). Berdasarkan hasil penelitian Putri et al. (2020) diketahui bahwa limbah kepala ikan kakap merah berpotensi untuk menjadi bahan baku pembuatan minyak ikan karena mengandung asam lemak esensial yang terdiri dari omega 3, omega 6 dan omega 9 masing-masing sebanyak 14,02\%, 4,06, dan 10,40\%. Ekstraksi dengan metode rendering basah pada suhu $80^{\circ} \mathrm{C}$ selama 1 jam menghasilkan minyak ikan terbaik dengan rendemen sebanyak $9,02 \%$, asam lemak bebas $1,02 \%$, angka asam $2,02 \%$ dan bilangan peroksida $0,98 \mathrm{meq} / \mathrm{kg}$.

Tingginya kandungan asam lemak esensial dalam minyak ikan dari kepala kakap merah menunjukkan bahwa semakin banyak pula jumlah asam lemak dengan ikatan rangkapnya yang mengakibatkan minyak ikan ini bersifat kurang stabil selama proses penyimpanan. Selain itu, pencampuran langsung minyak ikan sulit untuk dilakukan karena sifatnya yang sensitif terhadap oksidasi dengan adanya oksigen atau sinar ultraviolet, sehingga pengolahan lebih lanjut terhadap minyak ikan menjadi terbatas (Anwar et al., 2017; Idrus, 2013; Pang et al., 2017). Pengolahan minyak kedalam bentuk mikrokapsul akan memudahkan dalam penanganan dan pencampuran bahan aktif ke dalam bahan pangan lain dan meningkatkan stabilitas serta menjadikan bahan-bahan bersifat sensitif mudah untuk diolah lebih lanjut (Pang et al., 2017). Menurut Desai dan Park (2005), mikroenkapsulasi dengan pengeringan semprot (spray drying) merupakan alternatif untuk melindungi minyak ikan dan memperluas aplikasi penggunaannya, hal ini karena mikroenkapsulasi dapat mengurangi reaktivitas bahan aktif dari berbagai faktor lingkungan yang dapat menyebabkan kerusakan, seperti oksigen, panas, dan cahaya.

Penentuan bahan penyalut merupakan salah satu tahap penting dalam proses mikroenkapsulasi, bahan yang digunakan umumnya bersifat hidrofilik dan atau hidrofobik yang dapat membentuk film atau membentuk struktur seperti jaringan. Beberapa bahan penyalut yang biasa digunakan pada proses mikroenkapsulasi asam lemak omega 3 adalah protein, polisakarida, lipid, gum dan selulosa (Hasani et al., 2015; Sanguansri dan Ann Augustin, 2006). Polisakarida seperti maltodekstrin dapat membentuk lapisan (film) dan harganya murah, namun kapasitas emulsinya rendah, sedangkan dekstrin memiliki viskositas yang rendah sehingga dapat menghasilkan lapisan yang tipis (CanoHiguita et al., 2015; Yulinery dan Nurhidayat, 2016). Disisi lain, gum arab bersifat sangat mudah larut dan secara luas telah digunakan untuk mengenkapsulasi minyak dan rempah (CanoHiguita et al., 2015). Polisakarida yang dikombinasikan dengan gum arab diharapkan dapat menghasilkan dinding mikrokapsul yang baik. Penelitian Badee et al. (2012) menunjukkan bahwa penyalutan minyak pepermin menggunakan gum arab dan maltodekstrin memberikan rasio terbaik pada perbandingan 1:1. Berdasarkan hal tersebut, pelaksanaan penelitian ini ditujukan untuk mengkaji pengaruh proporsi bahan penyalut yang terdiri dari kombinasi polisakarida maltodekstrin dan dekstrin dengan gum arab terhadap karakteristik mikrokapsul minyak ikan dari limbah industri fillet ikan kakap merah.

\section{METODE}

Bahan baku yang digunakan dalam penelitian ini adalah limbah kepala ikan kakap merah yang dibeli dari PT. Inti Luhur Fuja Abadi, Pasuruan dengan ukuran berkisar antara 200-300 $\mathrm{g} /$ kepala, bahan pendukung yang digunakan yakni maltodextrin DE 10-12 (100\%), dekstrin $(100 \%)$, gum arab Tic Gums (teknis). Bahan kimia yang digunakan meliputi akuades, petroleum benzene Merck (PA), yang diperoleh dari Laboratorium Ilmu dan Teknologi Pangan UMM. $\mathrm{BF}_{3}, \mathrm{NaCl}$ jenuh, $\mathrm{Na}_{2} \mathrm{SO}_{4}$ anhidrat, heksana, gas $\mathrm{N}_{2}$ untuk uji profil asam lemak diperoleh dari PT. Saraswanti Indo Genetech Bogor.

Peralatan yang digunakan yakni freezer, panci stainless, kompor, talenan, pisau, gelas ukur, sentrifuse Hettich Mikro 220R, timbangan Ohaus, kain saring, botol kaca gelap, termometer, hot plate stirrer Romand Type HP03, magnetic stirrer, desikator, kurs porselen, kertas saring, soxhlet, waterbath Memmert HH4, labu lemak, kertas Whatman No.42, penyaring vakum merk Membran, oven Romand Type 50, plastik, sendok stainless, BUCHI mini spray dryer B-290, 
pompa vakum HanDen Model VP115, vortex merk Thermo Scientific, tube, optilab mikroskop digital, preparat, color reader Konica Minolta, vial dan alat analisis GC-FID Perkin Elmer.

\section{Preparasi Bahan Baku}

Preparasi bahan baku pada penelitian ini dilakukan dengan mengacu pada metode Putri et al. (2020). Limbah kepala ikan kakap merah dibersihkan dan dipisahkan dari kotoran seperti darah, sisik dan lain-lain. Selanjutnya dipotong dengan ukuran $1 \times 1 \times 1 \mathrm{~cm}$, kemudian ditimbang dengan berat masing-masing 250 $\mathrm{g} /$ kantong plastik, selanjutnya disimpan dalam keadaan beku $\left(-18{ }^{\circ} \mathrm{C}\right)$ hingga proses ekstraksi dilakukan.

\section{Ekstraksi Minyak Ikan}

Ekstraksi minyak ikan ini dilakukan dengan metode rendering basah yang mengacu pada metode ektraksi Putri et al. (2020). Limbah kepala kakap merah yang telah dipreparasi diletakkan ke panci stainless kemudian ditambahkan aquades dengan perbandingan 1:3 (250 g limbah kepala : $750 \mathrm{ml}$ aquades). Proses ekstraksi dilakukan pada suhu $80{ }^{\circ} \mathrm{C}$ selama 1 jam. Minyak yang berada pada permukaan airnya dipisahkan dengan cara diambil dengan sendok secara perlahan, kemudian dipisahkan dari pengotor lainnya seperti aquades dan padatan limbah yang terikut melalui sentrifugasi $\left(4000 \mathrm{rpm}, 25^{\circ} \mathrm{C}\right.$ selama 4 menit).

\section{Mikroenkapsulasi Minyak Ikan}

Proses enkapsulasi minyak ikan dilakukan dengan mengacu pada metode Fasikhatun (2010) yang dimodifikasi. Polisakarida dan gum arab sebanyak $15 \mathrm{~g}$ dicampurkan dalam keadaan kering, kemudian ditambahkan aquades sebanyak $35 \mathrm{~g}$. Campuran tersebut kemudian dihomogenkan menggunakan magnetic stirrer pada suhu $60^{\circ} \mathrm{C}$ selama 2 menit dengan kecepatan $1425 \mathrm{rpm}$. Emulsi kemudian didinginkan hingga mencapai suhu $40-45{ }^{\circ} \mathrm{C}$, kemudian $50 \mathrm{~g}$ minyak ikan ditambahkan sedikit demi sedikit pada emulsi dan dilakukan homogenisasi kembali selama 8 menit dengan kecepatan yang sama seperti sebelumnya. Terakhir emulsi yang sudah mengandung minyak ikan dikeringkan menggunakan spray dryer dengan suhu inlet $110-115{ }^{\circ} \mathrm{C}$, suhu outlet $80-85^{\circ} \mathrm{C}$, dan kecepatan pompa $40 \mathrm{rpm}$.
Tabel 1. Proporsi penambahan jenis penyalut dan emulsifier pada emulsi sebelum spray drying

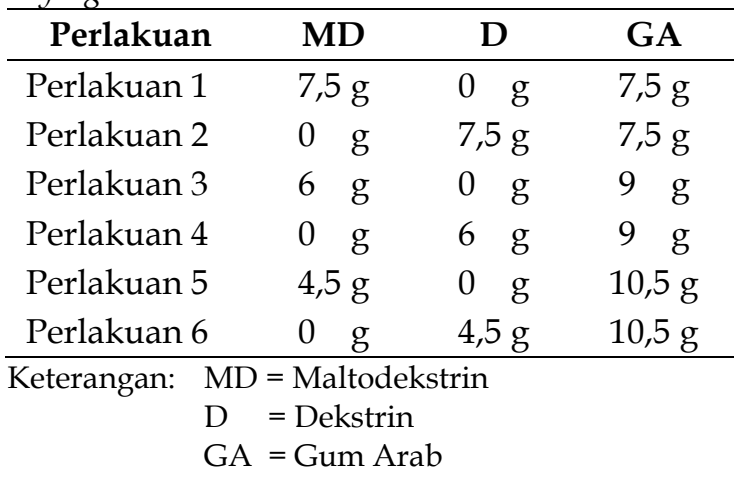

\section{Analisis Sifat Fisikokimia Mikrokapsul Minyak Ikan}

Analisis sifat fisikokimia mikrokapsul minyak ikan dari kepala kakap merah meliputi rendemen Quispe-Condori et al. (2011), kadar air dengan metode thermogravimetri (AOAC, 1995), kadar lemak dengan metode soxhlet (AOAC, 2005), kelarutan dengan metode gravimetri Fardiaz et al., (1992), ukuran mikrokapsul dengan alat optilab mikroskop digital Joko (2006), warna dengan alat color reader dan asam lemak dengan alat GC-FID (AOCS, 1993; AOAC, 2000; Nimal Ratnayake et al., 2006 dan SNI, 1992).

\section{Analisis Kelarutan Mikrokapsul Minyak Ikan}

Sebanyak 0,5 g mikrokapsul minyak ikan ditimbang lalu dilarutkan dalam $50 \mathrm{ml}$ aquades dan disaring dengan penyaring vakum. Sebelum digunakan, kertas saring dikeringkan terlebih dahulu dalam oven pada suhu $105^{\circ} \mathrm{C}$ sekitar 30 menit lalu ditimbang. Setelah proses penyaringan, kertas saring beserta residu bahan dikeringkan kembali dalam oven $105{ }^{\circ} \mathrm{C}$ selama 3 jam, didinginkan dalam desikator selama 15 menit lalu ditimbang. Persentase kelarutan dapat dihitung dengan Persamaan (1).

Kelarutan $=\left(1-\frac{c-b}{\frac{100-0 \% k a}{100} \times a}\right) \times 100 \%$

Keterangan:

$\mathrm{a}=$ berat sampel

$\mathrm{b}=$ berat kertas saring

$\mathrm{c}=$ berat kertas saring + residu

$\mathrm{ka}=$ kadar air sampel $(\% \mathrm{bb})$ 
Analisis Asam Lemak Mikrokapsul Minyak Ikan

Analisis asam lemak diawali dengan proses ekstraksi minyak ikan dari mikrokapsul minyak ikan menggunakan pelarut heksana. Selanjutnya sejumlah 2-3 g minyak ikan dipreparasi kemudian dimetilasi dengan menambahkan 1,5 ml larutan $\mathrm{KOH}$ 0,5 M dalam metanol ke dalam tabung ulir $10 \mathrm{ml}$. Larutan dipanaskan sampai suhu $100{ }^{\circ} \mathrm{C}$ dan didinginkan hingga suhu kamar, lalu ditambahkan $\mathrm{BF}_{3} 20 \%$ dalam methanol, kemudian dipanaskan kembali pada suhu $100{ }^{\circ} \mathrm{C}$. Selanjutnya larutan didinginkan dan dikocok sampai suhu larutan sekitar $30{ }^{\circ} \mathrm{C}$ dan ditambahkan $\mathrm{NaCl}$ jenuh dan heksana, kemudian dihomogenkan (vortex) selama 2 menit. Setelah terbentuk dua lapisan, lapisan fase organik dipindahkan ke tube $2 \mathrm{ml}$ yang berisi $\mathrm{Na}_{2} \mathrm{SO}_{4}$ anhidrat dan didiamkan selama 15 menit. Larutan dimasukkan ke dalam vial $2 \mathrm{ml}$. Kandungan asam lemak dideteksi menggunakan alat GC-FID Perkin Elmer. Suhu inlet diatur pada suhu $225^{\circ} \mathrm{C}$. Sampel sebanyak $0,1 \mu \mathrm{l}$ diinjeksikan ke dalam alat GC-FID yang dioperasikan menggunakan kolom Supelco SP2560 dengan spesifikasi panjang kolom 100 $\mathrm{m}$, diameter $0,25 \mathrm{~mm}$ dan ketebalannya $0,2 \mu \mathrm{m}$. Gas pembawa yang digunakan berupa $\mathrm{N}_{2}$ dengan kecepatan aliran $18 \mathrm{~cm} /$ detik. Oven diatur pada suhu $240{ }^{\circ} \mathrm{C}$ dengan tingkat kenaikan suhu $2,5{ }^{\circ} \mathrm{C} /$ menit. Hasil deteksi menggunakan FID dapat menunjukkan tipe asam lemak yang terkandung dalam minyak ikan, meliputi asam lemak jenuh, asam lemak tak jenuh, MUFA (Mono Unsaturated Fatty Acid), PUFA (Poly Unsaturated Fatty Acid), dan total asam lemak dalam sampel. Kromatogram hasil deteksi dapat digunakan untuk mengukur kadar masing-masing asam lemak.

\section{HASIL DAN PEMBAHASAN}

\section{Rendemen}

Hasil analisis statistik menunjukkan bahwa proporsi bahan penyalut tidak berpengaruh signifikan $(p>0,05)$ terhadap rendemen mikrokapsul minyak ikan. Rendemen mikrokapsul minyak ikan pada penelitian ini berkisar antara 17,75-25,08\% (Gambar 1), hasil ini mendekati rendemen mikrokapsul minyak ikan yang disalut gum akasia dan sodium alginat dengan penambahan tween-80 sebagai emulsifier yang dikeringkan dengan metode spray drying hasil penelitian Pang et al. (2017) yakni sebesar $20,93 \%$ dan mikrokapsul minyak ikan porapora yang disalut maltodekstrin dan gum arab hasil penelitian Hasibuan et al. (2017) yang berkisar antara 24,7-33,52\%. Rendemen hasil penelitian ini sejalan dengan hasil penelitian Yana et al. (2015) yang menunjukkan bahwa penggunaan bahan penyalut berupa maltodekstrin dan dekstrin tidak berpengaruh signifikan terhadap rendemen, namun perbedaan konsentrasi bahan penyalut yang digunakan berpengaruh terhadap rendemen yang dihasilkan. Semakin tinggi konsentasi bahan penyalut yang digunakan mengakibatkan semakin besar pula rendemen mikrokapsul yang dihasilkan, karena total padatan akan meningkat seiring meningkatnya konsentrasi bahan penyalut yang ditambahkan. Meningkatnya total padatan menyebabkan kenaikan berat produk dan rendemennya (Kamsiati, 2006; Hustiany, 2006). Rendemen yang dihasilkan pada penelitian ini tidak berbeda antara perlakuan satu dengan perlakuan lainnya karena konsentrasi bahan penyalut yang digunakan sama.

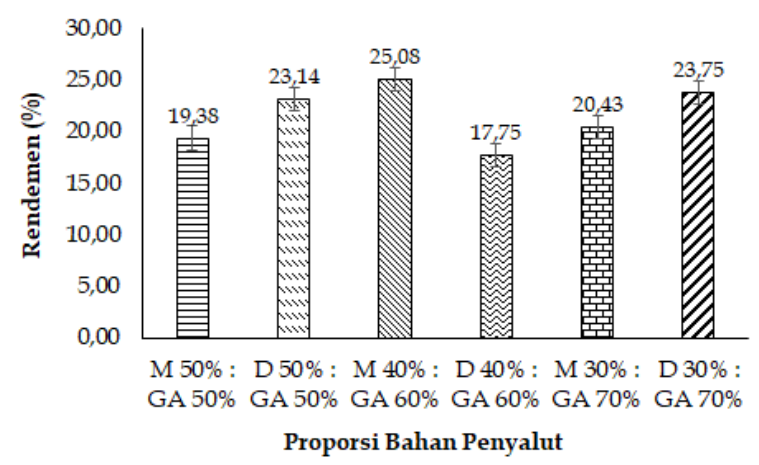

Gambar 1. Rendemen mikrokapsul minyak ikan dengan proporsi bahan penyalut berbeda

Selain itu, jenis bahan penyalut tidak mempengaruhi rendemen diduga karena emulsi yang terbentuk dari semua kombinasi perlakuan bersifat stabil karena terdapat penambahan gum arab. Menurut Gaonkar (1995), gum arab memiliki gugus glikoprotein (GP) dan arabinogalactan protein (AGP) yang berperan sebagai pengental dan pengemulsi. Idrus et al. (2013) juga menyatakan bahwa kestabilan dari emulsi sebelum proses pengeringan mempengaruhi hasil akhir mikrokapsulnya, hal ini karena apabila emulsi yang terbentuk stabil maka droplet minyak yang terbentuk akan terlapisi dengan baik dalam emulsi baik sebelum maupun ketika pengeringan berlangsung sehingga droplet 
minyak dalam mikrokapsul terjamin keberadaannya, sehingga efisiensi proses enkapsulasi menjadi tinggi dan rendemen yang dihasilkan semakin banyak. Tahap homogenisasi merupakan tahap yang sangat penting untuk memperoleh serbuk mikrokapsul berkualitas baik (Hasibuan et al., 2017).

Gum arab juga berperan cukup besar dalam pembentukan lapisan (film) yang menstabilkan emulsi serta melindungi dropletdroplet minyak selama pengeringan sehingga menghasilkan efisiensi enkapsulasi yang tinggi. Efisiensi enkapsulasi yang tinggi akan menghasilkan rendemen yang tinggi pula (Marshall, 1996; Badee et al., 2012).

\section{Kadar Air}

Hasil analisis statistik menunjukkan bahwa proporsi bahan penyalut tidak berpengaruh signifikan $(\mathrm{p}>0,05)$ terhadap kadar air mikrokapsul minyak ikan. Kadar air mikrokapsul minyak ikan pada penelitian ini berkisar antara 9,77-13,87\% (bb) (Gambar 2). Jumah total bahan penyalut dan emulsifier yang ditambahkan dalam emulsi sama beratnya, hal ini mengakibatkan kadar air mikrokapsul yang dihasilkan cenderung sama karena kadar air lebih dipengaruhi oleh jumlah penyalut yang ditambahkan bukan jenisnya. Menurut Masters (1979), bahan pengisi dapat mempercepat proses pengeringan, meningkatkan total padatan dan menurunkan kadar air bahan pangan. Selain itu, maltodekstrin dan dekstrin memiliki karakter yang cenderung sama dalam menyalut bahan yakni membentuk lapisan tipis dan penguapan air dari emulsinya mudah, sejalan dengan pernyataan Takashige et al., (2019) bahwa jenis bahan penyalut tidak mempengaruhi kadar air. Semakin banyak jumlah hidrokoloid dan partikel padatan dalam emulsi akan menurunkan kadar air dan mempercepat mikrokapsul mencapai berat konstan (Nugroho, 2006; Ramadhia et al., 2012).

Kadar air mikrokapsul yang dihasilkan mendekati kadar air mikrokapsul minyak sawit mentah dengan penyalut maltodekstrin dan natrium kaseinat pada penelitian Saputra (2014) yang berkisar antara 3-9\% dan kadar air mikrokapsul minyak ikan pora-pora dengan penyalut maltodekstrin dan gum arab hasil penelitian Hasibuan et al. (2017) yang berkisar antara 4,8-7,3\%. Menurut Yuliani et al., (2007) pada produk berupa mikrokapsul hasil spray drying, kadar air yang baik berkisar antara 2$6 \%$. Semakin rendah kadar air mikrokapsul, maka akan lebih awet karena pertumbuhan mikroba terhambat, meminimalisir reaksi kimia yang dapat merusak dan tidak diinginkan misalnya hidrolisis dan oksidasi lemak (Syafi'i et al., 2016; Hasibuan et al., 2017).

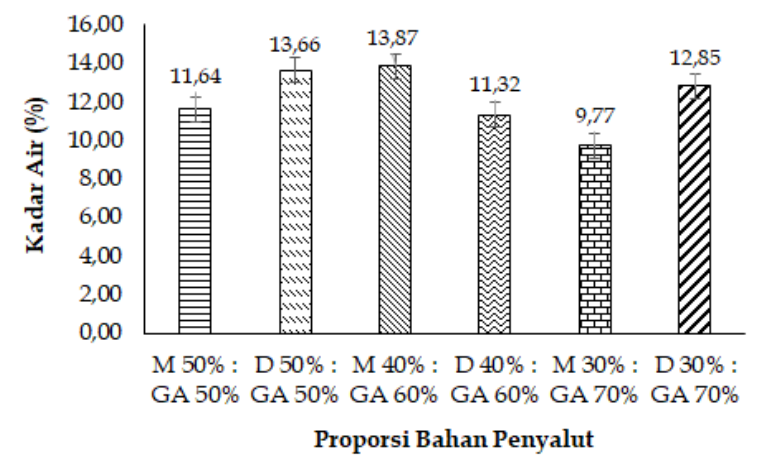

Gambar 2. Kadar air mikrokapsul minyak ikan dengan proporsi bahan penyalut berbeda

Faktor perlakuan pada penelitian ini tidak berpengaruh terhadap kadar air mikrokapsul yang dihasilkan, sehingga tidak sesuai dengan penyataan Hui (1993) yang menyatakan bahwa semakin banyak maltodekstrin yang ditambahkan mengakibatkan semakin tinggi pula kadar air mikrokapsulnya karena maltodekstrin terdiri atas granula-granula bersifat hidrofilik. Gugus hidroksil pada maltodekstrin akan mengikat air dan meningkatkan kekentalan emulsi. Pada mikrokapsul yang disalut dengan dekstrin, proses pengeringan akan berlangsung cepat, karena ketika senyawa dekstrin bereaksi dengan air maka gugus-gugus hidroksilnya (unit D-glukosa) akan membentuk ikatan hidrogen dengan molekul-molekul air tersebut. Hal ini mengakibatkan bila air diuapkan akan terjadi kristalisasi karena gugus hidroksil membentuk ikatan hidrogen dengan gugus hidroksil lainnya.

\section{Kelarutan}

Hasil analisis statistik menunjukkan bahwa konsentrasi gum arab berpengaruh signifikan $(p<0,05)$ terhadap kelarutan mikrokapsul minyak ikan. Kelarutan mikrokapsul minyak ikan pada penelitian ini berkisar antara 71,95-73,87\% (Gambar 3), sesuai dengan hasil penelitian Fasikhatun (2010) yang menyatakan bahwa kelarutan mikrokapsul minyak sawit merah dengan bahan penyalut maltodekstrin dan gum arab berkisar antara $60,31-78,87 \%$ dan kelarutan mikrokapsul minyak sawit mentah dengan bahan penyalut maltodekstrin dan natrium kaseinat hasil penelitian Saputra (2014) yakni 70\%. 
Maltodekstrin dan dekstrin memiliki sifat yang mudah larut dalam air, sehingga akan meningkatkan kelarutan mikrokapsulnya (Koswara, 2009; Syafi'i et al., 2016; Setyaningsih et al., 2009). Dekstrin memiliki sifat pembasahan dan pendispersi yang baik karena terdapat bagian molekul yang hidrofilik, sehingga ketika mikrokapsul yang dibuat dengan bahan penyalut dekstrin dilarutkan dalam air gugus hidrofilik tersebut dapat mengikat atau memerangkap air lebih banyak dan daya larutnya semakin meningkat (Rosida et al., 2013).

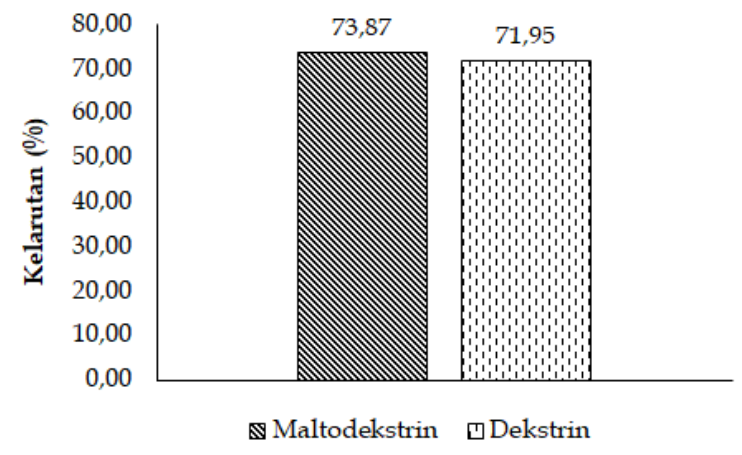

Gambar 3. Kelarutan mikrokapsul minyak ikan dengan bahan penyalut berbeda

Hasil penelitian ini sesuai dengan hasil penelitian Fasikhatun (2010) yang menunjukkan bahwa penambahan minyak akan menurunkan kelarutan mikrokapsul, dimana rasio penyalut pada formula dengan penambahan minyak $100 \%$ tidak berbeda nyata terhadap kelarutan. Tingkat kelarutan mikrokapsul tidak dipengaruhi oleh jenis bahan penyalut yang digunakan, melainkan dipengaruhi oleh jumlah bahan penyalut yang digunakan. Semakin banyak bahan penyalut yang digunakan maka minyak ikan selaku bahan inti akan tersalut atau terlapisi secara sempurna, sehingga proses mikroenkapsulasi berlangsung efektif dan tidak terbentuk lapisan minyak di permukaan mikrokapsul mengakibatkan kelarutan mikrokapsul meningkat (Botrel et al., 2014).

Semakin besar nilai kelarutan maka akan semakin baik, mengingat bahwa tujuan enkapsulasi adalah untuk meningkatkan stabilitas bahan yang dienkapsulasi serta memperluas aplikasinya (Desai dan Park, 2005). Tingkat kelarutan mikrokapsul tertinggi dimiliki oleh formula 1 dengan konsentrasi emulsifier 50\% yakni sebesar 77,25\% (Tabel 2), namun tidak berbeda nyata dengan kelarutan mikrokapsul minyak ikan yang dihasilkan dari formula 3 dengan konsentrasi emulsifier $70 \%$ yakni $74,75 \%$. Hasil ini mendekati kelarutan mikrokapsul pada penelitian Fasikhatun (2010) yang menunjukkan bahwa minyak sawit merah yang disalut maltodekstrin dan gum arab pada perbandingan 1:3 memiliki kelarutan sebesar $78,87 \%$, sedangkan pada perbandingan $3: 3$ sebesar $76,47 \%$ namun pada penelitian ini semakin banyak jumlah emulsifier (gum arab) yang digunakan maka semakin tinggi pula kelarutannya. Hal tersebut disebabkan gum arab yang ditambahkan dalam konsentrasi tinggi $(>12 \%)$ akan menghasilkan emulsi yang stabil dengan ukuran droplet kecil dan seragam karena terdapat protein yang membentuk kompleks dengan arabinogalactan dalam gum arab. Protein ini apabila konsentrasinya rendah tidak mampu menyelaputi droplet-droplet minyak secara sempurna, sehingga menyebabkan terjadinya flokulasi dan pengelompokan. Selain itu, penambahan gum arab dalam jumlah sedikit akan membentuk droplet-droplet minyak ikan yang tidak seragam serta mengakibatkan terjadinya flokulasi yang mengganggu kelarutan mikrokapsul (Williams et al., 1990).

Tabel 2. Kelarutan mikrokapsul minyak ikan dengan konsentrasi emulsifier berbeda

\begin{tabular}{cc}
\hline Konsentrasi Gum Arab (\%) & Kelarutan (\%) \\
\hline 50 & $77,25^{\mathrm{b}}$ \\
60 & $66,73^{\mathrm{a}}$ \\
70 & $74,75^{\mathrm{b}}$ \\
\hline
\end{tabular}

Hasil uji tingkat kelarutan diduga juga dipengaruhi oleh kadar minyak yang tidak terkapsulkan. Botrel et al., (2014) menyatakan bahwa apabila pada bagian permukaan dinding mikrokapsul terdapat minyak yang semakin banyak, maka penyebaran air ke permukaan mikrokapsul akan terhambat. Minyak pada permukaan mikrokapsul juga menyebabkan kondisi lingkungannya menjadi lebih hidofobik, sehingga mengakibatkan mikrokapsul menjadi lebih sulit larut dan akhirnya banyak residu padatan yang tertinggal di kertas saring.

\section{Kadar Lemak}

Hasil analisis statistik menunjukkan bahwa proporsi bahan penyalut tidak berpengaruh $(p>0,05)$ terhadap kadar lemak mikrokapsul minyak ikan. Kadar lemak mikrokapsul minyak ikan pada penelitian ini berkisar antara 10,63-15,65\% (Gambar 4), hasil ini mendekati kadar lemak hasil blending 
minyak ikan dan sawit merah terenkapsulasi hasil penelitian Dewita et al. (2016) yang berkisar antara 13,60-17,11\% dan kadar lemak mikrokapsul minyak ikan hasil samping penepungan ikan lemuru dengan penyalut lesitin, gum arab dan gelatin hasil penelitian Yogaswara (2008) yakni 17,76\%.

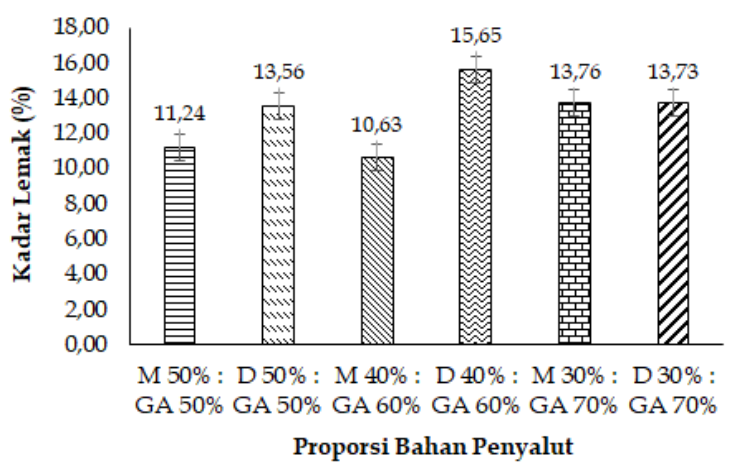

Gambar 4. Kadar lemak mikrokapsul minyak ikan dengan proporsi bahan penyalut berbeda

Hasil analisis ragam menunjukkan bahwa proporsi bahan penyalut berupa maltodekstrin dan dekstrin tidak berpengaruh terhadap kadar lemak mikrokapsul minyak ikan. Hal ini kemungkinan dipengaruhi oleh penggunaan gum arab sebagai bahan penyalut, menurut Marshall (1996), gum arab diduga cukup besar perannya dalam pembentukan lapisan (film) yang menstabilkan emulsi karena dalam gum arab terdapat gugus arabinogalactan protein dan glikoprotein yang berfungsi sebagai pengemulsi, kandungan protein dalam gum arab bila digabungkan dengan polisakarida akan menyebabkan unitunit reologi menghasilkan sel yang terbentuk dari benang-benang protein yang diisi oleh granula pati, sehingga membentuk kompleks protein-pati yang padat dan selama proses pengeringan berlangsung droplet minyak dapat terlindungi (Khamidah et al., 2019). Gum arab dengan konsentrasi yang semakin tinggi akan meningkatkan stabilitas emulsi, karena dalam gum arab terkandung rantai polipeptida hidrofobik dan hidrofilik yang berfungsi untuk menstabilkan sistem emulsi. Kandungan karbohidratnya mampu menghambat flokulasi melalui perpaduan tolakan elektrostatik dan sterik (El - Kheir et al., 2008).

Desktrin memiliki kemampuan menghasilkan viskositas rendah dan menghasilkan film yang berkekuatan tinggi. Emulsi dengan viskositas rendah sangat dibutuhkan pada proses mikroenkapsulasi karena menyebabkan proses mikroenkapsulasi berjalan efektif, sehingga semakin banyak minyak yang tersalut dalam mikrokapsul. Viskositas emulsi yang tinggi tidak dikehendaki karena dapat menyebabkan penyumbatan sehingga proses penyemprotan terhambat. Selain itu, emulsi dengan viskositas tinggi akan sulit untuk diinjeksikan ke dalam alat spray dryer dan dapat menghambat proses pengeringan pada tabung inlet, sehingga menghasilkan mikrokapsul berkadar air tinggi dan menempel pada tabung pengering (clogging) (Yuslinawati, 2014).

\section{Ukuran Mikrokapsul Minyak Ikan}

Hasil analisis statistik menunjukkan bahwa proporsi bahan penyalut tidak berpengaruh $\quad(p>0,05)$ terhadap ukuran mikrokapsul minyak ikan. Ukuran mikrokapsul hasil penelitian ini berkisar antara 1277,73-1821,82 $\mu \mathrm{m}$ (Gambar 5). Ukuran mikrokapsul minyak ikan pada penelitian ini menunjukkan nilai yang seragam. Hal ini disebabkan jenis bahan penyalut dan konsentrasi emulsifier tidak mempengaruhi ukuran dari mikrokapsul yang dihasilkan karena alat spray dryer menghasilkan distribusi ukuran partikel yang konsisten dan kisaran ukuran yang lebih kecil dibandingkan dengan metode lain, sehingga ukuran partikelnya seragam (Asyhari, 2013; Kasih, 2014). Selain itu, penambahan jumlah atau konsentrasi bahan penyalut yang sama akan menghasilkan ukuran mikrokapsul yang cenderung seragam, karena ukuran atau diameter mikrokapsul berbanding lurus dengan jumlah bahan penyalut yang ditambahkan. Semakin banyak bahan penyalut yang ditambahkan maka semakin besar pula ukuran mikrokapsul yang dihasilkan (Asyhari, 2013).

Semua perlakuan menghasilkan mikrokapsul dengan ukuran yang telah sesuai serta termasuk dalam kisaran ukuran mikrokapsul yakni antara 1-5000 $\mu \mathrm{m}$ (Nugraheni et al., 2015; Istiyani, 2008). Ukuran mikrokapsul yang hasil penelitian ini lebih besar dibandingkan ukuran mikrokapsul minyak ikan dengan penambahan tepung porang sebagai pengemulsi yang berkisar antara 2-10 $\mu \mathrm{m}$, mikrokapsul minyak sawit mentah dengan penyalut maltodekstrin dan isolat protein kedelai yang berkisar antara 1-12 $\mu \mathrm{m}$ juga mikrokapsul ekstrak kulit buah manggis yang berkisar antara 13,12-26,33 $\mu \mathrm{m}$ (Anwar et al., 2017; Hasrini et al., 2017; Kasih, 2014). Hal ini kemungkinan pengaruhi oleh ukuran nozzle yang digunakan, ukuran nozzle dan padatan emulsi yang besar akan 
menghasilkan mikrokapsul yang besar dengan lemak bebas yang rendah (Onwulata, 2005). Ukuran nozzle dari alat spray dryer yang digunakan pada penelitian ini berkisar antara 10-60 $\mu \mathrm{m}$.

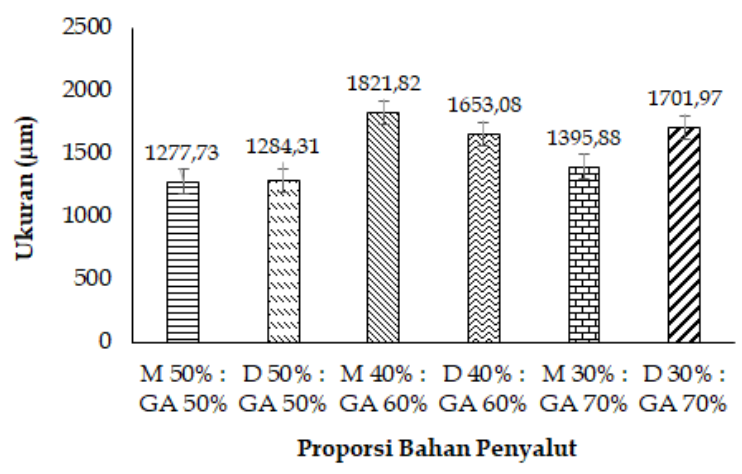

Gambar 5. Ukuran mikrokapsul minyak ikan dengan proporsi bahan penyalut berbeda

\section{Warna}

Hasil analisis statistik menunjukkan bahwa proporsi bahan penyalut tidak berpengaruh $(p>0,05)$ terhadap warna mikrokapsul minyak ikan. Warna mikrokapsul pada penelitian ini terdiri dari nilai L (Lightness) antara 53,3-59,8, a (red) antara 1,6-7,3 dan b (yellow) antara 17,1-21,8 (Tabel 3). Semakin tinggi nilai $\mathrm{L}$ menunjukkan bahwa mikrokapsul memiliki warna yang semakin cerah, hal ini dikehendaki karena menurut Pang et al. (2017) semakin tinggi nilai L menyebabkan produk dapat memperoleh nilai komoditas yang baik. Secara fisik, mikrokapsul minyak ikan dari kepala ikan kakap merah berwarna putih kekuningan dan hasil pengukuran menunjukkan nilai yang juga cenderung kemerahan.

Proporsi bahan penyalut yang berbeda tidak mempengaruhi warna mikrokapsul yang dihasilkan karena warna mikrokapsul cenderung dipengaruhi oleh bahan inti, bukan bahan penyalutnya. Sebagaimana dinyatakan oleh Francis (2003), warna kemerahan mikrokapsul dipengaruhi oleh kandungan hemoglobin pada produk, sedangkan warna kuning dipengaruhi kandungan lemak pada produknya. Masters (1979) menambahkan bahwa, rendahnya kadar air produk yang dikeringkan dapat meningkatkan retensi warna. Berdasarkan pernyataan tersebut, kadar lemak dan kadar air mikrokapsul yang cenderung sama mengakibatkan mikrokapsul memiliki warna yang seragam pula. Warna yang seragam ini juga dikarenakan mikroenkapsulasi dapat mencegah perubahan warna dan bau serta dapat menjaga stabilitas zat inti yang dipertahankan dalam jangka waktu yang lama (Reineccius, 2004).

Warna mikrokapsul hasil penelitian ini menyerupai warna mikrokapsul minyak sawit mentah yang disalut dengan maltodekstrin dan gum arab hasil penelitian Fasikhatun (2010) yang berkisar antara 53,80-57.51 dengan nilai a berkisar antara (-0,11)-2,80 dan $b$ berkisar antara 29,44-33,67 dan mikrokapsul minyak ikan hasil spray drying pada penelitian Pang et al., (2017) dengan nilai L, a dan b masingmasing sebesar 66,06, 12,24 dan 20,30.

Tabel 3. Warna mikrokapsul minyak ikan dengan konsentrasi emulsifier berbeda

\begin{tabular}{llll}
\hline \multirow{2}{*}{ Bahan Penyalut } & \multicolumn{3}{l}{ Warna } \\
\cline { 2 - 4 } & $\mathrm{L}$ & $\mathrm{a}$ & $\mathrm{b}$ \\
\hline MD 50\% : GA 50\% & $59,5^{\mathrm{a}}$ & $3,3^{\mathrm{a}}$ & $21,2^{\mathrm{a}}$ \\
D 50\% : GA 50\% & $56,4^{\mathrm{a}}$ & $4,3^{\mathrm{a}}$ & $19,4^{\mathrm{a}}$ \\
MD 40\% : GA 60\% & $53,3^{\mathrm{a}}$ & $1,6^{\mathrm{a}}$ & $17,3^{\mathrm{a}}$ \\
D 40\% : GA 60\% & $56,2^{\mathrm{a}}$ & $7,3^{\mathrm{a}}$ & $21,2^{\mathrm{a}}$ \\
MD 30\% : GA 70\% & $59,8^{\mathrm{a}}$ & $3,6^{\mathrm{a}}$ & $21,8^{\mathrm{a}}$ \\
D 30\% : GA 70\% & $57,1^{\mathrm{a}}$ & $2,4^{\mathrm{a}}$ & $17,1^{\mathrm{a}}$ \\
\hline
\end{tabular}

\section{Asam Lemak Penyusun}

Hasil pengujian asam lemak menunjukkan bahwa proses mikroenkapsulasi mampu mempertahankan kandungan asam lemak tidak jenuh dalam minyak ikan dari kepala ikan kakap merah (Tabel 4). Kandungan asam lemak mikrokapsul minyak ikan tidak jauh berbeda dibandingkan kandungan asam lemak dari minyak ikannya. Terdapat 27 jenis asam lemak yang terkandung dalam mikrokapsul minyak ikan dari kepala kakap merah (Tabel 4) dengan asam lemak dominan terdiri dari asam palmitat (C 16:0), asam stearat (C 18:0) dan asam oleat (C 18:1) dengan jumlah masing-masing sebesar 31,93\%, 12,88\% dan $12,08 \%$. Mikrokapsul juga mengandung asam lemak esensial bagi tubuh seperti asam arakidonat (AA), asam eikosapentaenoat (EPA) dan asam dokosaheksaenoat (DHA) serta omega 3, omega 6 dan omega 9 sejumlah $14,17 \%, 4,35 \%$ dan $12,53 \%$. Namun beberapa asam lemak seperti asam butirat, asam kaproat, asam kaprilat dan asam kaprat tidak terdeteksi dalam mikrokapsul, kemungkinan besar diakibatkan kandungan asam lemak tersebut rusak selama proses mikroenkapsulasi berlangsung. Sebagaimana dinyatakan oleh Ketaren (1986) bahwa asam butirat dan asam kaproat tergolong sebagai asam lemak tak 
jenuh berantai pendek yang mudah menguap dan mengalami hidrolisis. Kandungan asam lemak dalam mikrokapsul yang menyerupai kandungan asam lemak dalam minyak ikannya diduga dikarenakan proses mikroenkapsulasi mampu meningkatkan stabilitas dan menjaga produk dari kerusakan. Mikroenkapsulasi dapat melindungi kestabilan asam lemak, melindungi bahan dari lingkungannya, juga telah dilaporkan mampu memperlambat atau menghindarkan minyak dari oksidasi. Proses mikroenkapsulasi menggunakan alat spray dryer sebelumnya telah dilakukan untuk menghasilkan mikrokapsul minyak kaya asam lemak omega 3 dari hasil penepungan lemuru dan konsentrat asam lemak tak jenuh dari minyak ikan patin (Hasani et al., 2015; Quispe-condori et al., 2011; Yuliasari et al., 2016; Estiasih et al., 2008; Khamidah et al., 2019).

Tabel 4. Profil asam lemak mikrokapsul minyak ikan dari kepala ikan kakap merah

\begin{tabular}{|c|c|c|c|}
\hline \multirow{2}{*}{ Nama asam lemak } & \multirow{2}{*}{ Struktur } & \multicolumn{2}{|l|}{ Jumlah (\%) } \\
\hline & & Minyak Ikan & Mikrokapsul Minyak Ikan \\
\hline Asam butirat & C $4: 0$ & 0,12 & - \\
\hline Asam kaproat & C 6:0 & 0,10 & - \\
\hline Asam kaprilat & C 8:0 & 0,45 & - \\
\hline Asam kaprat & C 10:0 & 0,37 & - \\
\hline Asam laurat & C 12:0 & 2,16 & 0,32 \\
\hline Asam tridekanoat & C 13:0 & 0,12 & 0,12 \\
\hline Asam miristat & C 14:0 & 7,52 & 7,40 \\
\hline Asam pentadekanoat & C 15:0 & 1,27 & 1,27 \\
\hline Asam palmitat & C 16:0 & 29,85 & 31,93 \\
\hline Asam heptadekanoat & C 17:0 & 2,10 & 2,18 \\
\hline Asam stearat & C 18:0 & 13,55 & 12,88 \\
\hline Asam archidat & C 20:0 & 0,92 & 0,80 \\
\hline Asam heneikosanoat & C 21:0 & 0,31 & 0,29 \\
\hline Asam behenat & C 22:0 & 0,91 & 0,84 \\
\hline Asam trikosanoat & C 23:0 & 0,46 & 0,27 \\
\hline Asam lignoserat & C 24:0 & 0,55 & 0,62 \\
\hline Total SFA & & 60,76 & 58,92 \\
\hline Asam miristoleat & C $14: 1$ & 0,35 & 0,30 \\
\hline Asam pentadekenoat & C $15: 1$ & 0,19 & 0,18 \\
\hline Asam palmitoleat & C $16: 1$ & 7,19 & 6,97 \\
\hline Asam heptadekenoat & C $17: 1$ & 0,66 & 0,60 \\
\hline Asam oleat $(\omega 9)$ & C $18: 1$ & 10,40 & 12,08 \\
\hline Asam eikosenoat & C 20:1 & 0,80 & 0,70 \\
\hline Asam erukat ( $\omega 9)$ & C 22:1 & - & 0,46 \\
\hline Asam nervonat & C 24:1 & 0,98 & 0,84 \\
\hline Total MUFA & & 20,57 & 22,13 \\
\hline Asam linoleat $(\omega 6)$ & C $18: 2$ & 0,68 & 1,05 \\
\hline Asam linolenat $(\omega 3)$ & C $18: 3$ & 0,12 & 0,23 \\
\hline Asam eikosadienoat & C 20:2 & 0,46 & 0,44 \\
\hline Asam eikosatrienoat $(\omega 6, \omega 3)$ & C 20:3 & 0,37 & 0,37 \\
\hline Asam arakidonat (AA) $(\omega 6)$ & C 20:4 & 3,14 & 3,09 \\
\hline Asam eikosapentaenoat ( $\omega 3)$ & C 20:5 & 3,04 & 2,81 \\
\hline Asam dokosadienoat & C 22:2 & 0,12 & - \\
\hline Asam dokosaheksaenoat $(\omega 3)$ & C 22:6 & 10,74 & 10,95 \\
\hline Total PUFA & & 18,67 & 18,95 \\
\hline Total Asam Lemak Omega 3 & & 14,02 & 14,17 \\
\hline Total Asam Lemak Omega 6 & & 4,06 & 4,35 \\
\hline Total Asam Lemak Omega 9 & & 10,40 & 12,53 \\
\hline
\end{tabular}

Keterangan:

SFA : Saturated Fatty Acid (asam lemak jenuh)

MUFA : Monounsaturated Fatty Acid (asam lemak tak jenuh tunggal)

PUFA : Polyunsaturated Fatty Acid (asam lemak tak jenuh ganda) 
Bahan penyalut yang digunakan pada penelitian ini terdiri dari maltodekstrin, dekstrin dan gum arab. Kombinasi bahan penyalut ini menghasilkan mikrokapsul minyak ikan yang mampu mempertahankan kandungannya. Hal ini dikarenakan maltodekstrin merupakan material penyalut yang dapat melindungi zat aktif terenkapsulasi terhadap reaksi oksidasi dan mengurangi masalah aglomerasi selama masa penyimpanan sehingga meningkatkan stabilitas produk, sedangkan gum arab merupakan komplek heteropolisakarida yang umum digunakan sebagai material pembungkus pada proses mikroenkapsulasi menggunakan spray dryer (Gabas et al., 2007; Bemiller et al., 1996).

Kandungan asam lemak omega 3 yang tidak berbeda nyata antara mikrokapsul minyak ikan kakap merah dan minyak ikan kakap merah menunjukkan bahwa proses mikroenkapsulasi terbukti mampu melindungi asam lemak dari kerusakan. Hasil pengujian asam lemak menunjukkan bahwa kandungan omega 3 setelah proses mikroenkapsulasi cenderung tetap. Hasil ini tidak sesuai dengan hasil penelitian sebelumnya yang dilakukan oleh Hasibuan et al. (2017) mengenai proses mikroenkapsulasi minyak ikan pora-pora dengan penyalut maltodekstrin dan gum arab yang menunjukkan bahwa komposisi asam lemak setelah proses mikroenkapsulasi mengalami perubahan, secara keseluruhan asam lemak tak jenuh tunggal mengalami peningkatan dari $41,71 \%$ menjadi $73,68 \%$, sedangkan asam lemak tak jenuh ganda menurun dari $23,67 \%$ menjadi $7,42 \%$. Hal ini kemungkinan diakibatkan oleh perbedaan kondisi pada proses mikroenkapsulasi. Namun hasil penelitian ini telah sejalan dengan pernyataan Howe et al. (2002) bahwa dalam wujud mikrokapsul asam lemak omega 3 berada dalam bentuk terlindungi dan dapat meminimalisir pengaruh oksidasi terhadap kualitas sensoris produknya. Selain itu, mikroenkapsulasi juga dapat menutupi bau amis pada produk akhirnya, sehingga kesempatan produk untuk diaplikasikan pada berbagai produk lainnya meningkat (Garg et al., 2006).

Selama ini mikrokapsul asam lemak omega 3 masih diimpor dan belum diproduksi dalam skala industri di Indonesia (Estiasih et al., 2008). Hasil pengujian kandungan asam lemak menunjukkan bahwa proses mikroenkapsulasi pada minyak ikan yang diekstrak dari limbah kepala ikan kakap merah berpotensi untuk dijadikan salah satu alternatif untuk memenuhi permintaan pasar akan mikrokapsul asam lemak omega 3 yang terus meningkat seiring meningkatnya kesadaran publik akan pentingnya mengkonsumsi asam lemak tersebut (Baik et al., 2004).

\section{SIMPULAN}

Proporsi bahan penyalut yang berbeda tidak berpengaruh nyata terhadap rendemen, kadar air, kadar lemak, ukuran dan warna, namun berpengaruh nyata terhadap kelarutan mikrokapsul minyak ikan. Proses mikroenkapsulasi juga mampu mempertahankan kandungan asam lemak omega yang terdapat dalam minyak, dibuktikan dengan hasil pengujian asam lemak yang menunjukkan bahwa dalam mikrokapsul minyak ikan dari kepala ikan kakap merah pada perlakuan 4 dengan perbandingan bahan penyalut dekstrin dan gum arab 2:3 ini mengandung omega 3, omega 6 dan omega 9 sebesar 14,17\%, 4,35\% dan $12,53 \%$.

\section{DAFTAR PUSTAKA}

Anwar, S, -H., Br. Ginting, B, -M., Aisyah, Y., Safriani, -N., 2017. Pemanfaatan tepung porang (Amorphophallusoncophyllus) sebagai penstabil emulsi M/A dan bahan penyalut pada mikrokapsul minyak ikan. Jurnal Teknologi Industri Pertanian. 27, 76-88. https://doi.org/10.24961/j.tek.ind.pert.201 7.27.1.76

Badee, A, Z, -M., Kader, E, A, -E., Aly, -M., 2012. Microencapsulation of peppermint oil by spray drying. Australian Journal of Basic and Applied Sciences. 6, 499-504. http://www.ajbasweb.com/old/ajbas/20 12/Nov\%202012/499-504.pdf

Baik, M, -Y., Suhendro, E, -L., Nawar, W, -W., McClements, D, -J., Decker, E, -A., Chinachoti, -P., 2004. Effects of antioxidants and humidity on the oxidative stability of microencapsulated fish oil. Journal of the American Oil Chemist' Society. 81, 355-360. https://doi.org/10.1007/s11746-004-0906-7

Botrel, D, -A., de Barros Fernandes, R, -V., Borges, S, -V., Yoshida, M, -I., 2014. Influence of wall matrix systems on the 
properties of spray-dried microparticles containing fish oil. Food Research International. 62, 344-352. https://doi.org/10.1016/j.foodres.2014.02.003 Cano-Higuita, D, -M., Malacrida, C, -R., Telis, V, R, -N., 2015. Stability of curcumin microencapsulated by spray and freeze drying in binary and ternary matrices of maltodextrin, gum arabic and modified starch. Journal Food Processing and Preservation. 39, 2049-2060. https://doi.org/10.1111/jfpp.12448

Desai, K, G, -H., Park, H, -J., 2005. Recent developments in microencapsulation of food ingredients. Drying Technology. 23, 1361-1394. https://doi.org/10.1081/DRT-200063478

Dewita., Syahrul., Desmelati., Lukman, -S., 2016. Inovasi bubur instan dan cookies berbasis konsentrat protein ikan patin yang difortifikasi minyak sawit merah dan minyak ikan patin terenkapsulasi. Jurnal Pengolahan Hasil Perikanan Indonesia. 18, 315-320. https://doi.org/10.17844/jphpi.v18i3.11215

Estiasih, -T., Ahmadi, -K., Nisa, C, -F., 2008. Karakteristik mikrokapsul minyak kaya asam lemak omega-3 dari hasil samping penepungan lemuru. Jurnal Teknologi dan Industri Pangan. 19, 121-130. https://journal.ipb.ac.id/index.php/jtip/ article/view/343

Gabas, A, -L., Telis, V, R, -N., Sobral, P, J, A., Telis-Romero, -J., 2007. Effect of maltodextrin and arabic gum in water vapor sorption thermodynamic properties of vacuum dried pineapple pulp powder. Journal of Food Engineering. 82, 246-252. https://doi.org/10.1016/j.jfoodeng.2007.02.029

Garg, M, -L., Wood, L, -G., Singh, -H., Moughan, P, -J., 2006. Means of delivering recommended levels of long chain n-3 polyunsaturated fatty acids in human diets. Journal of Food Science. 71, R66-R71. https://doi.org/10.1111/j.17503841.2006.00033.x

Hasani, -M., Rad, A, H, -E., Hosseini, M, -M., Noghabi, M, -S., 2015. Physicochemical characteristic of microencapsulated fish oil by freeze-drying using different combinations of wall materials. Biosciences Biotechnology Research Asia 12, 45-51. https://doi.org/10.13005/bbra/2171

Hasibuan, N, -E., Thamrin, Muis, -Y., 2017. Mikroenkapsulasi minyak ikan porapora (mystacoleucus padangensis) menggunakan metode spray drying untuk aplikasi nutrisi makanan. Jurnal Kimia Mulawarman. 14(2), 108-114. http://jurnal.kimia.fmipa.unmul.ac.id /index.php/JKM/article/view/466

Hasrini, R, -F., Zakaria, F, -R., Adawiyah, D, -R., Suparto, I, -H., 2017. Mikroenkapsulasi minyak sawit mentah dengan penyalut maltodekstrin dan isolat protein kedelai. Jurnal Teknologi dan Industri Pangan. 28, 10-19. https://doi.org/10.6066/jtip.2017.28.1.10

Howe, P, R, -C., Downing, J, -A., Grenyer, B, F, -S., Grigonis-Deane, E, -M., Bryden, W, -L., 2002., Tuna fishmeal as a source of DHA for n-3 PUFA enrichment of pork, chicken, and eggs. Lipids. 37, 1067-1076. https://doi.org/10.1007/s11745-002-1002-3

Idrus, -S., 2013. Mikroenkapsulasi minyak ikan yang mengandung asam lemak omega-3 menggunakan gum arab sebagai bahan pelapis. Majalah Biam. 9, 23-29. http://dx.doi.org/10.29360/mb.v9i1.1997

Idrus, -S., Affifudin, S, -Z., Ratumalessy, D, J., 2013. Identifikasi dan mikroenkapsulasi minyak ikan yang mengandung asam lemak omega-3. Jurnal Riset Industri. 7(1), 53-62. http://ejournal1.kemenperin.go.id/jri /article/view/3238

Kamsiati, -E., 2006. Processing tomato powder (Licopersicon esculentum Mill.) by "foam-Mat drying". Jurnal Teknologi Pertanian. 7, 113-119. https://jtp.ub.ac.id/index.php/jtp/article/ view/221

Khamidah, S, -Z., Hastarini, -E., Fardiaz, -D., Budijanto, -S., 2019. Mikroenkapsulasi konsentrat asam lemak tak jenuh dari minyak ikan patin. Jurnal Teknologi dan Industri Pangan. 30, 143-151. https://doi.org/10.6066/jtip.2019.30.2.143

La Ifa., Artiningsih, -A., Julniar, -J., Suhaldin., 2018. Pembuatan kitosan dari sisik ikan kakap merah. Journal of Chemical Process Engineering. 3(1), 47-50. https://doi.org/10.33536/jcpe.v3i1.19 5

Nimal Ratnayake, W, -M., Hansen, S, -L., Kennedy, M, -P., 2006. Evaluation of the CPSil 88 and SP-2560 GC columns used in the recently approved AOCS official method Ce 1h-05: Determination of cis-, trans-, saturated, monounsaturated, and polyunsaturated fatty acids in vegetable or non-ruminant animal oils and fats by capillary GLC method. Journal of the 
Jurnal Teknologi Pertanian Vol. 22 No. 2 [Agustus 2021] 89-100

Karakteristik Mikrokapsul Minyak Ekstrak dari Kepala Kakap Merah [Putri dkk]

American Oil Chemists' Society. 83, 475-488. https://doi.org/10.1007/s11746-006-1230-y

Nugraheni, -A., Yunarto, -N., Sulistyaningrum, N., 2015. Optimasi formula mikroenkapsulasi ekstrak rimpang temulawak (Curcuma xanthorrhiza roxb.) dengan penyalut berbasis air. Jurnal Kefarmasian Indonesia. 5, 98-105. https://doi.org/10.22435/jki.v5i2.4404.98-105

Nugroho, E, -S., 2006. Pengaruh konsentrasi gum arab dan dekstrin terhadap sifat fisik dan tingkat kesukaan temulawak (Curcuma xanthorhiza roxb) madu instan. Jurnal Logika Values Innovation Perfection. 3(2). https://doi.org/10.20885/logika.vol3.iss2.art7

Pang, Y., Duan, X., Ren, G., Liu, W., 2017. Comparative study on different drying methods of fish oil microcapsules. Journal of Food Quality. 2017, 1-7. https://doi.org/10.1155/2017/1612708

Putri, D, -N., Wibowo, Y, M, -N., Santoso, E, -N., Romadhani, -P., 2020. Sifat fisikokimia dan profil asam lemak minyak ikan dari kepala kakap merah (Lutjanus malabaricus). Agritech. 40, 31. https://doi.org/10.22146/agritech.47039

Quispe-Condori, -S., Saldaña, M, D, -A., Temelli, F., 2011. Microencapsulation of flax oil with zein using spray and freeze drying. $L W T$ Food Science and Technology. 44, 1880-1887. https://doi.org/10.1016/j.lwt.2011.01.005

Ramadhia, M., Kumalaningsih, S., Santoso, I., 2012. The making of aloe vera powder (Aloe vera L.) with foam-mat drying method. Jurnal Teknologi Pertanian. 13, 125-137. https://jtp.ub.ac.id/index.php/jtp/article/ view/367

Reineccius, G, -A., 2004. The spray drying of food flavors. Drying Technology. 22, 1289-1324. https://doi.org/10.1081/DRT-120038731

Rosida, Sarofa, -U., Widiyanto, -S., 2013. Kualitas fisik santan bubuk dengan penambahan emulsifier lesitin dan pengisi dekstrin. Jurnal Rekapangan. 7(2), 230-241. http://repository.upnjatim.ac.id/1385/1/3.4 _KUALITAS_FISIK_SANTAN_BUBUK.pdf

Sanguansri, L, Augustin, MA. 2006. 'Microencapsulation and Delivery of Omega-3 Fatty Acids'. Dalam John Shi (ed). Functional Food Ingredients and Nutraceuticals - Processing Technologies. Taylor and Francis, USA
Saputra, S, -H., 2014. Mikroenkapsulasi Bkaroten dari minyak sawit mentah untuk suplemen pro vitamin A. Jurnal Riset Teknologi Industri. 8, 11-17. https://doi.org/10.26578/jrti.v8i15.1548

Setyaningsih, -D., Rahmalia, -R., Sugiyono., 2009. The study on microencapsulation of vanilla extract. Jurnal Teknologi Industri Pertanian. 19, 64-70. https://journal.ipb.ac.id/index.php/jurnaltin /article/view/1066

Syafi'i, -F., Wijaya, C, -H., Nurtama, -B., 2016. Optimasi proses pembuatan bubuk oleoresin lada (Piper nigrum) melalui proses emulsifikasi dan mikroenkapsulasi. Agritech. 36, 128. https://doi.org/10.22146/agritech.128 56

Takashige, -S., Iwamoto, -S., Shiga, -H., Kakizaki, -Y., Yamaya, -Y., Ushirosako, -A., Maruyama, -K., Adachi, -S., Yoshii, -H., 2019. Stability of fish oil encapsulated in spray-dried powders coated with starch particles. Food Science and Technology Research. 25, 363-371. https://doi.org/10.3136/fstr.25.363

Yana, M, -F., Kusnadi, -J., 2015. Pembuatan yogurt berbasis kacang tunggak (Vigna unguiculata) dengan metode freeze drying (kajian jenis dan konsentrasi bahan pengisi). Jurnal Pangan dan Agroindustri. 3, 1203-1213. https://jpa.ub.ac.id/index.php/jpa/a rticle/view/243

Yuliani, -S., Desmawarni, Harimurti, -N., Yuliani, S, -S., 2007. Pengaruh laju air umpan dan suhu inlet spray drying pada karakteristik mikrokapsul oleoresin jahe. Jurnal Pascapanen. 4, 18-26. http://ejurnal.litbang.pertanian.go.id/index .php/jpasca/article/view/10034

Yuliasari, -S., Fardiaz, -D., Andarwulan, -N., Yuliani, -S., 2016. Karakteristik enkapsulat minyak sawit merah dengan pengayaan $\beta$ karoten. Informatika Pertanian. 25, 107. https://doiorg/10.21082/ip.v25n1.2016.p107-116

Yulinery, -T., Nurhidayat, N., 2016. Analisis viabilitas probiotik lactobacillus terenkapsulasi dalam penyalut dekstrin dan jus markisa (Passiflora edulis). Jurnal Teknologi Lingkungan. 13, 109121. https://doi.org/10.29122/jtl.v13i1.1411 